\title{
ANALISIS YURIDIS HAK ASASI MANUSIA DI DALAM REVITALISASI PEMASYARAKATAN
}

\author{
Chika Panji Ardiansyah \\ Politeknik IImu Pemasyarakatan \\ chikapanji@gmail.com \\ Kota Depok, 16512, Indonesia
}

\begin{abstract}
This paper seeks to analyze whether the treatment for inmates under the Revitalization of Correctional Implementation policy is in accordance with a human rights perspective. This research aims to provide information regarding the Correctional process and contribute to the study of Correctional Sciences. It is expected that readers to recognize the role of Corrections. The method used in this research is qualitative with normative and conceptual approaches. This study reveals that the treatment of inmates under the Revitalization of Correctional Implementation policy is in line with a human rights perspective. Revitalization of Correctional Implementation that emphasizes attitudes and behavioural change of inmates by arranging the placement test to optimize the process within the Correctional Institutions, is held with respect to human rights.
\end{abstract}

Keywords: Correctional; Human Rights; Juridical Analysis; Revitalization

Abstrak

Tulisan ini berupaya untuk menganalisa dan memahami perlakuan terhadap narapidana di Lapas pada kebijakan Revitalisasi Penyelenggaraan Pemasyarakatan apakah masih sesuai dengan perspektif Ham. Manfaat penelitian ini memberikan infromasi kepada pembaca tentang proses Pemasyarakatan dan memberikan sumbangsih dalam kajian IImu Pemasyarakatan. Sehigga diharapkan pembaca menjadi teredukasi dengan peran Pemasyarakatan. Metode yang digunakan adalah kualitatif. Pendekatan yang digunakan dalam metode penelitian menggunakan metode yuridis normative dan pendekatan konseptual. Hasil Penelitian mengungkapkan bahwa Revitalisasi Penyelenggaran Pemasyarakatan menggunakan aspek-aspek Hak Asasi Manusia dalam perlakuan terhadap narapidana. Revitalisasi Penyelenggaraan Pemasyarakatan yang menekankan perubahan sikap dan perilaku narapidana dengan melakukan pentahapan-pentahapan penempatan yang juga sebagai optimalisasi proses di dalam organisasi Pemasyarakatan yang di dalamnya tetap menggunakan instrumen Hak Asasi Manusia.

Kata Kunci: Analisis Yuridis; Hak Asasi Manusia; Pemasyarakatan; Revitalisasi;

Received: DD/MM/YY; Revised: DD/MM/YY; Accepted: DD/MM/YY

Journal Publicuho is licensed under a Creative Commons Attribution 4.0 International License.

10.35817/jpu.v3i1.11514 


\section{PENDAHULUAN}

Negara dan Hak asasi manusia (Ham) memiliki kaitan yang sangat erat. Dimana ajaran Ham menjadi salah satu subtansi dalam penyelenggaraan negara. Berbagai negara di dunia menunjukkan bahwa dirinya merupakan negara yang berlandasakan Ham. Bahkan doktrin negara hukum (rechsstaat) harus memberikan penjaminan terhadap pengakuan Ham. Hal ini membuktikan bahwa Ham menjadi poin penting dalam menjalankan roda pemerintahan sebagai bentuk eksistensi negara.

Ham diartikan hak yang di miliki manusia sejak dia dilahirkan dan tidak dapat di ganggu gugat oleh siapapun yang diberikan Tuhan Yang Maha Esa karena kodratnya sebagai manusia.(Aswandi \& Roisah, 2019) Ham yang melekat pada individu perlu adanya pengakuan oleh negara sebagai bentuk kehadiran negara pada pengakuan dan perlindugan atas Ham. Secara internasional pengakuan Ham di mulai pada tahun 1948 oleh Perserikatan Bangsa-Bangsa dalam Resolusi PBB nomor 217 (III) yang melahirkan Universal Declaration Of Human Right yang kemudian secara yuridis agar di patuhi negara anggotanya di ikat dalam perjanjian unilateral.(Matompo, 2014) Sedangkan berlakunya aturan HAM di Indonesia sejak di berlakukanya Undang-Undang Nomor 39 Tahun 1999 tentang Hak Asasi Manusia sebagai bentuk pelaksanaan Tap MPR Nomor XVIUMPR/1998.

Bentuk penegakan Ham oleh negara harus di lakukan di setiap aspek penyelenggaraan negara. Salah satu aspek yang akan di bahas dalam peneltian ini adalah perlakuan negara terhadap para pelanggar hukum. Pemasyarakatan dianggap cocok diterapkan di Indonesia sebagai Sistem perlakuan terhadap para pelanggar hukum. Konsepsi ini pertama kali di kenalkan tokoh hukum di Indonesia yakni Dr.Sahardjo,S.H yang saat itu ia ucapkan dalam pidatonya yang berjudul "Pohon Beringin Pengayoman" dalam penganugrahan Doktor Honorus Causa (HC) oleh Universitas Indonesia. Setelah sekian lama pemikiran konsepsi Pemasyarakatan mulai di implementasikan dengan hadirnya UndangUndang No 12 Tahun 1995 tentan Pemasyarakatan.

Konsepsi Pemasyarakatan mengajarkan dengan memandang narapidana merupakan manusia yang mempunyai konflik dengan masyarakat. Narapidana melakukan kejahatan karena adanya ketertinggalan dengan masyarakat dimana di dalam kondisi sosial masyarakat terjadi perkembangan kehidupan yang kompleks sehingga apabila individu tidak bisa mengikuti perkembangan tersebut, individu akan melakukan upaya untuk bisa mencapainya sehingga tidak di pungkiri ada jalan di tempuh individu yang didasarkan pada norma sosial atau yang menyimpang dari norma sosial yang berlaku di masyarakat. Penyimpangan norma sosial yang mengarah pada tindak kriminal inilah yang akan di jawab oleh Pemasyarakatan, bagaimana melakukan treatment terhadap individu yang telah melakukan tindak pidana pelanggaran dan/ kejahatan. Pemasyarakatan merupakan 
perlakuan terhadap individu-individu yang melakukan pelanggaran hukum untuk dapat dipulihkan kesatuan hidup, penghidupan, dan kehidupan yang memiliki esensi mengembalikan serta menerima narapidana di lingkungan masyarakat.

Kompleksitas kehidupan sosial masyarakat yang kian cepat yang juga di pengaruhi era globalisasi berdampak signifikan terhadap tantangan yang di hadapi Pemasyarakatan. Tingkat kejahatan yang semakin meningkat yang membuat kondisi Lembaga Pemasyarakatan (Lapas) atau Rumah Tahanan (Rutan) menjadi over capacity (Kondisi kelebihan kapasitas). Dimana data Direktorat Jendral Pemasyarakatan yang di liris dalam laman smslap.ditjenpas.go.id per tanggal 2 Maret 2020 Jumlah narapidana dan tahanan 269.063 orang sedangkan kapasitas hunian 132.273 orang, sehingga terjadi over capacity telah mencapai 103 \%. Akibat over capacity di dalam Lapas dan Rutan terjadi kondisi krisis akibat padatnya huniaan (over crowding).(Eddyono, 2017)

Dampak over crowding dalam Lapas dan Rutan sangat besar. Dimana jumlah penghui yang berlebih di Lapas dan Rutan membuat kualitas pemenuhan hak dan pengelolaan yang rendah akibat dari beban kerja petugas yang melebihi kapasitas serta adanya cara-cara kekerasan guna memudahkan pengaturan penghuni.(Latifah, 2019) Dalam aspek anggaran akibat kondisi yang ada terjadi lonjakan anggaran makan penghuni yang signifikan dimana anggaran makan narapidana pada tahun 2018 sebanyak 1,391 triliun pada tahun 2019 menjadi sebnayak 1,79 triliun.(Ryandi, 2019) Hal tersebut juga mendorong meningkatnya kondisi stres narapidana yang berdampak tidak stabilnya psikologi narapidana. Akibat kondisi yang demikian terjadi potensi gangguan keamanan dan ketertiban sangatlah besar. Hal tersebut terbukti dengan adanya permasalahan kerusuhan yang terjadi di Lapas atau Rutan, penyelundupan narkoba, Pemberontakan narapidana, kebakaran, pelarian narapidana, dan pelanggaran Ham. Kondisi yang semakin berlarut-larut tanpa adanya solusi yang efektif akan berdampak besar pada tujuan organisasi yang tidak akan terwujud, yaitu pemulihan kesatuan hidup, kehidupan, dan penghidupan narapidana sebgaimana amanat dari Undang-undang Pemasyarakatan.

Walapun upaya penanggulan kondisi over crowded melalui pembentukan lapas terbuka telah dilaksanakan akan tetapi di dalam penelitian mengungkapkan terjadi kendala implementasi karena faktor regulasi dan narapidana sendiri.(Jufri, 2017) Kendala dalam optimalisasi penempatan narapidana adanya keengganan narapidana untuk di pindahkan ke Lapas terbuka, adanya ke khawatiran narapidana untuk melarikan diri karena Lapas terbuka memiliki sistem keamanan dan pengamanan yang minim di banding Lapas regular, Pelibatan Pembimbing Kemasyarakatan (PK) Balai Pemasyarakatan (Bapas) yang di rasa kurang dalam hal memberikan rekomendasi atau pertimbangan untuk memindah narapidana ke Lapas terbuka, ketidak pahaman petugas terhadap Lapas terbuka yang membuat persepsi mengenai lapas terbuka menjadi tidak sama, serta pemindahan 
Journal Publicuho

ISSN 2621-1351 (online), ISSN 2685-0729 (print)

Volume 3 Number 1 (February-April), (2020) pp.91 - 102

Accredited SINTA SK.NOMOR 28/E/KPT/2019

Open Access at: http://ojs.uho.ac.id/index.php/PUBLICUHO/index

DOI: $10.35817 /$ jpu.v3i1.11514

narapidana ke Lapas terbuka hanya di dasarkan perintah dan permintaantaan karena kurangnya penghuni atau pun adanya kepentingan tertentu selain itu dalam hal pemilihan narapidana yang tidak sesuai dengan prosedur dimana narapidana yang di pilih di dasarkan pada sidang tim pengamat pemasyarakatan (TPP) yang menitik beratkan pada masa pidana namun secara assessment tidak bisa di tempatkan di Lapas terbuka padahal penempatan harus di dasarkan pada keduanya.(Haryono, 2018) Padahal Lapas terbuka merupakan Community Base Corrections ( $C B C$ ), mengarahkan pembinaan narapidana pada partisipasi masyarakat serta mengupayakan kesiapan yang matang bagi narapidana untuk berintegrsi di masyarakat.(Haryono, 2018)

Metode Pembinaan yang diterapkan pada Lapas terbuka yang mengacu konsep Community Base Corrections ( $C B C$ ) dengan mengembangkan hubungan baru yang baik dengan lingkungan masyarakat dengan menyatukan narapidana dengan nilai-nilai dan norma masyarakat.(Fajriando, 2019) Narapidana diberikan asimilasi dengan memberikan pengawasan keamanan yang minim. Kegiatan yang di implementasikan dalam metode ini dengan melaksanakan di dalam dan di luar lembaga. Dimana narapidana di dapat bekerja dengan pihak ketiga atau pun melaksanakan kegiatan di dalam tembok dengan diberikan waktu tertentu.

Melihat kondisi yang demikian perlunya ide/ gagasan maupun kebijakan guna mengatasi permasalahan tersebut agar tidak semakin parah guna penguatan lembaga. Kebijakan yang ada diarahkan pada pengelolaan majanerial Pemasyarakatan yang aman dan kondusif untuk dapat membina narapidana agar mereka memiliki kemampuan keterampilan sosial dan wirausaha. Muncul ide Revitalisasi melalui Peraturan Menteri Hukum dan Ham Nomor 35 Tahun 2018 tentang Revitalisasi Penyelenggaraan Sistem Pemasyarakatan. Hal ini diartikan upaya melakukan optimalisasi penyelenggaraan Pemasyarakatan dalam perlakuan terhadap narapidana, tahanan, dan klien serta melindungi kepemilikan barang bukti.

Revitalisasi Penyelenggaran Sistem Pemasyarakatan menjadi metode dalam pelaksanaan treatment. Ada 4 aspek yang menjadi fokus yaitu Pelayanan Tahanan, Pembinaan Narapidana, Pembimbingan Klien, dan Pengelolaan barang sitaan dan barang rampasan. Dalam penelitian ini yang akan menjadi batasan penelitian pada aspek embinaan narapidana. Rumusan masalah dalam penelitian ini akan membahas Bagaimana penerapan kebijakan revitalisasi Pemasyararakatan dalam upaya pemenuhan hak asasi narapidana?

Penelitian ini bertujuan untuk menganalisis dan memahami secara mendalam tentang treatment yang ada tentang Revitalisasi penyelenggaran Sistem Pemasyarakatan dalam pembinaan narapidana dalam perspektif Ham. Manfaat dalam penelitian ini agar 
dapat memberikan infromasi kepada pembaca tentang proses Pemasyarakatan dan memberikan sumbangsih dalam kajian Ilmu Pemasyarakatan. Sehigga diharapkan pembaca menjadi teredukasi dengan peran Pemasyarakatan dan selain itu juga dapat menambah kajian-kajian keilmuan di bidang Ilmu Pemasyarakatan.

\section{METODE}

Metode penelitian yang di gunakan ialah metode kualitatif. Pendekatan yang digunakan dalam metode penelitian menggunakan metode yuridis normative dan pendekatan konseptual. Dalam penelitian ini sumber data yang digunakan adalah (a) Data primer, seperti aturan hukum atau pun kebijakan terkait judul, (b) Data sekunder, seperti buku referensi, artikel atau jurnal, laporan atau hasil penelitian, dan media cetak atau elektronik terkait judul. Sedangkan teknik pengumpulan data pada penelitian menggunakan metode Library Research (Penelitian Kepustakaan). Studi kepustakaan merupakan teknik pengumpulan data dengan penelaahan buku-buku, literatur-literatur, catatan-catatan, dan laporan-laporanhasil penelitian yang terkait dengan topik yang menjadi pembahasan. Analisa data yang digunakan adalah analisa kualitatif, dimana analisa dengan memilah bahan hukum, artikel atau jurnal yang ada.

\section{HASIL DAN PEMBAHASAN}

Hak asasi manusia dalam perlakuan bagi pelanggar hukum menjadi isu yang menarik untuk di bahas. Pelanggar hukum di dalam masyarakat merupakan orang yang disingikirkan mereka dianggap penyakit yang harus di basmi, tetapi di sisi lain mereka merupakan warga negara yang memiliki hak sebagai warga negara untuk juga di lindungi. Pengakuan Ham terhadap pelanggar hukum tetap harus menjadi atensi negara dan perlu selalu di upayakan. Karena mereka merupakan manusia yang memiliki hak kodrati. Selain itu Republik Indonesia sebagai negara hukum, dimana doktrin negara hukum mengakui eksistensi Ham tidak terkecuali para pelanggar hukum. Eksisteni hak asasi bagi pelanggar hukum di Indonesia di atur dalam Undang-undang Nomor 39 Tahun 1999 tentang Hak Asasi Manusia dan Undangundang No 12 Tahun 1995 tentang Pemasyarakatan.(Michael, 2017) Perwujudan Ham bagi pelanggar hukum adalah terselenggaranya konsepsi Sistem Pemasyarakatan. (Michael, 2017) Karena di dalam konsepsi yang di tuliskan dalam undang-undang Pemasyarakatan telah mengandung nilai-nilai Ham. Nilai yang di maksud termaktub dalam Pasal 5 Undang-undang No 12 Tahun 1995 tentang Pemasyarakatan, yakni Pengayoman, persamaan perlakuan dan pelayanan, pendidikan, pembimbingan, penghormatan harkat dan martabat manusia, kehilangan kemerdekaan merupakan satu-satunya penderitaan, dan terjaminnya hak untuk tetap berhubungan dengan keluarga dan orang-orang tertentu. Selain itu, penerapan perlakuan terhadap narapidana dengan memperhatikan hak-hak narapidana yakni (a) Hak ibadah sesuai agama atau kepercayaan yang di anutnya; (b) Hak perawatan, yakni 
Journal Publicuho

ISSN 2621-1351 (online), ISSN 2685-0729 (print)

Volume 3 Number 1 (February-April), (2020) pp.91 - 102

Accredited SINTA SK.NOMOR 28/E/KPT/2019

perawatan rohani atau jasmani; (c) Hak memperoleh pendidikan dan pengajaran, (d) Hak layanan kesehatan dan makanan llayak; (e) Hak menyampaikan keluhan; (f) Hak memperoleh bahan bacaan dan mengikuti siaran media massa yang tidak dilarang; (g) Hak memperoleh upah atau premi atas pekerjaannya; (h) Hak menerima kunjungan keluarga, penasihat hukum, atau orang tertentu lainnya; (i) Hak atas pengurangan masa pidana (remisi); (j) Hak kesempatan berasimilasi termasuk cuti mengunjungi keluarga, (k) Hak mendapatkan pembebasan bersyarat, (I) Hak mendapatkan cuti menjelang bebas; dan (m) hak-hak lain yang sesuai peraturan perundang-undangan.

Peran Pemasyarakatan dalam penegakan hak asasi warga binaan pemasyarakatan (sebutan bagi pelanggar hukum yang menjadi binaan ) dilaksanakan oleh unit pelaksana teknis dalam bidang Pemasyarakatan salah satunya Lapas. Lapas sebagai pelaksana pidana memiliki peran penting dalam hal perubahan perilaku narapidana. Lapas dituntut untuk dapat mengembalikan pemulihan narapidana, dimana narapidana dapat kembali dan di terima di masyarakat serta tidak mengulangi tindak pidananya. Tantangan dan tuntutan Lapas akibat kompleksitas kehidupan di masyarakat yang berimplikasi pada jumlah penghuni yang kian meningkat yang membuat Lapas menjadi over crowding yang membuat tujuan Pemasyarakatan untuk Reintegrasi Warga Binaan Pemasyarakatan (WBP) sulit di wujudkan perlu segera diatasi. Ide atau gagasan Revitalisasi Pemasyarakatan di anggap cocok untuk menjawab kondisi yang ada. Melalui Peraturan Menteri Hukum dan Ham Nomor 35 Tahun 2018 tentang Revitalisasi Penyelenggaraan Sistem Pemasyarakatan sebagai bentuk keseriusan dan babak baru upaya dalam mengatasi kompleksitas permasalahan Pemasyarakatan.

Revitalisasi Pemasyarakatan menjadi sorotan perhatian publik. Tidak hanya dalam hal efektivitasnya akan tetapi juga dalam penerpannya dalam penegakan Ham. Dalam penelitian ini pembatasan permasalahan yang akan di bahas terkait penerpan Hak Asasi Narapidanan dalam Revitalisasi Pemasyarakatan. Revitaliasasi Penyelenggaraan Sistem Pemasyarakatan menerapakan metode pembinaan. Dimana pada PP 31 Tahun 1999 menyatakan pembinaan merupakan kegiatan yang dilakukan guna meningkatkan kualitas ketaqwaan kepada Tuhan Yang Maha Esa, intelektual, sikap \& perilaku, profesional, kesehatan jasmani dan rohani narapidana. Dan di dalam peraturan yang sama teknis pelaksanaan pembinaan narapidana melibatkan 3 unsur yakni (1) Pembina Pemasyarakatan, merupakan petugas yang diberikan tanggung jawab oleh Kepala Lapas untuk melaksankan tugas di bidang pembinaan. Tugas dari wali adalah mengamati, menanganiserta menampingi pembinaan narapidana. (2) Pembimbing Kemasyarakatan (Pk), merupakan petugas Pemasyarakatan yang melaksanakan penelitian kemasyarakatan (litmas), pengawasan, pembimbingan, dan pendampingan terhadap Klien ketika masa dan 
setelah peradilan pidana.(Peraturan Menteri Hukum Dan Hak Asasi Manusia Republik Indonesia Nomor 35 Tahun 2018 Tentang Revitalisasi Penyelenggaraan Pemasyarakatan, 2018) (3) Pengaman Pemasyarakatan,merupakan petugas yang diberikan wewenang untuk melaksankan upaya pencegahan, penindakan, penanggulangan dan pemulihan gangguan keamanan dan ketertiban (kamtib)

Pelaksanaan pembinaan narapidana melalui Revitalisasi Penyelenggaraan Pemasyarakatan di bagi menjadi 4 Tahapan sebagai klasifikasi penempatan yaitu Lapas Super Maximum Security, Lapas Maximum Security, Lapas Medium Security,Lapas Minimum Security. Penggunaan klasifikasi penempatan narapidana memiliki tujuan agar dapat melakukan kategorisasi sesuai dengan kebutuhan dan resiko narapidana sehingga treatment yang diberikan pada narapidana berhasil. Karena pada konsep ini sangat menekankan perubahan perilaku.

Lapas Super Maximum Security merupakan klasifikasi Lapas yang diperuntukan bagi narapidana dengan tingkat resiko tinggi. Sebagaimana di dalam aturan revitalisasi Pemasyrakatan unsur yang meklasifikasikan narapidana bersiko tinggi meliputi narapidana tersebut beresiko membahayakan keamanan negara dan atau membahayakan keselamatan masyarakat. Dimana unsur tersebut akan menjadi perhatian dalam penilian yang akan di sampaikan dalam Penelitian Kemasyarakatan (Litmas) dan di bahas dalam sidang tim pengamat pemasyarakatan (TPP) untuk di berikan rekomendasi dalam penempatannya. Dalam sistem pembinaanya metode yang digunakan adalah pemisahan individual. Penempatan narapidana di tempatkan masing-masing satu kamar atau one men one cell. Sistem ini mirip dengan Sistem Pensylvania dalam menempatkan narapidanan. Perbedaan dengan Sistem Pensylvania pada sistem ini adalah pada pola pembinaan dan tujuan pemenjaraan. Dalam Sistem Pensylvania tujuan pemenjaraan adalah penjeraan bagi narapidana dan balas dendam akan perbuatan yang telah di lakukannya.(Aryana, 2015) Pola Pembinaan yang diterapkan pada Sistem Pensylvania dengan memberikan pekerjaan narapidana di dalam selnya dan hanya memberikan bacaan berupa kitab suci serta diberikan larangan yang ketat untuk berkomunikasi dengan orang lain dan menerima kunjungan dari orang lain.(Aryana, 2015) Sedangkan dalam Revitalisasi Penyelenggaraan Pemasyarakatan tujuan pemenjaraan pada tahap Super Maximum Security adalah memunculkan kesadaran diri narapidana yang menitik beratkan pada berubahnya sikap dan perilaku narapidana yang berimplikasi pada penurunan tingkat resiko dan melindungi masyarakat. Pola Pembinaan dalam tahap ini yakni:

1. pembinaan kesadaran beragama, merupakan pembinaan kepribadian yang diberikan guna meningkatkan ketaqwaan kepada Tuhan Yan Maha Esa sehingga narapidana memiliki kesadaran beragama yang kuat yang berdampak peningkatan kualitas kecerdasan emosionalnya; 
2. pembinaan kesadaraan berbangsa dan bernegara, merupakan pembinaan guna membentuk narapidana menjadi manusia yang memiliki karakter warga negara yang baik sadar akan kehidupan berbangsa dan juga menimbulakan jiwa nasionalisme, patriotisme,gotong-royong, dan toleransi;(Winarto, 2018);

3. pembinaan kesadaran hukum, merupakan kegiatan guna meingkatakan kesadaran dan mematuhi hukum sehingga narapidana termotivasi untuk taat pada aturan dan tidak melanggar hukum kembali yang memiliki dampak buruk bagi dirinya dan orang lain;

4. Konseling Psikologi, merupakan pembinaan yang penting bagi narapidana dengan adanya pembinaan tersebut narapidana dapat memecahkan masalahnya, menetapkan dan mencapai apa yang menjadi tujuan atau harapannya, meningkatkan kemampuan narapidana berkomunikasi, dan menjaga tingkat emosi serta stres yang di alami narapidana.(Joseph, 2017)

Dalam hal pembatasan narapidana yang berada dalam tahap ini tidak diberikan hak reintegrasi seperti remisi, asimilasi, cuti mengunjungi keluarga, pembebasan bersyarat, cuti menjelang bebas dan cuti bersyarat. Pembatasan pada klasifikasi narapidana yang ditempatkan pada Lapas Super Maximum Security di tinjau dalam persepektif Ham, pada dasarnya pemenjaran merupakan pembatasan gerak bagi individu untuk secara leluasa bergerak bebas di masyarakat sebagaimana dalam konsepsi Pemasyarakatan. Di dalam tahap tersebut terdapat pembatasan-pembatasan gerak one men one cell hingga mengarah pada proses reintegrasi sosial narapidana. Apabila menganalisis kebijakan tersebut di dalam konsep Ham pembatasan yang dilakukan untuk tujuan tertentu di perbolehkan. Hal ini mengacu pada Ham yang terogolong non-derogable right (Ham yang tidak bisa dikurangi pemenuhannya) dan derogable rights (Hak yang bisa di kurangi pemenuhannya) (Matompo, 2014). Dalam konteks perlakuan terhadap narapidana pada tahap Super Maximum Security hal tersebut merupakan derogable rights (Hak-hak yang dapat di kurangi pemenuhannya) dimana narapidana yang di klasifikasikan merupakan narapidana yang memiliki resiko tinggi dimana syarat narapidana yang masuk merupakan narapidana membahayakan keamanan negara dan atau membahayakan keselamatan masyarakat. Hal tersebut berimplikasi pada keadaan kondusifitas suatu negara, apabila narapidana tersebut tidak di tangani secara serius maka di khawatirkan akan mengganggu ketertiban di masyarakat yang menimbulkan keresahan dan menganggu kedaulatan negara. Pembatasan tersebut di perkuat dengan Pasal 28J ayat (2) Undang-undang Dasar 1945 yang menyatakan setiap orang harus tunduk dan patuh terhadap pembatasan yang di tetapkan sebagai bentuk pengakuan dan menjamin hak orang lain dengan pertimbangan moral, nilai-nilai agama, keamanan, dan ketertiban umum dalam suatu 
masyarakat sebgaimana yang di amanatkan dalam Undang-undang Dasar 1945. Dalam pembatasan hak yang tidak di perbolehkan adalah yang bertentangan dengan nonderogable right, sebagaimana di nyatakan dalam Pasal 28l ayat (1) Undang-undang Dasar 1945 yaitu hak hidup, hak tidak disiksa, hak kemerdekaan pikiran dan hati nurani, hak beragama, hak tidak diperbudak, hak diakui sebagai pribadi di hadapan hukum, dan hak tidak dituntut atas dasar hukum yang berlaku surut. Selain pembatasan hak tersebut narapidana tetap diberikan hak-haknya sesuai dengan hak narapidana dan tidak mengabaikan sistem pembinaan sebagai nilai-nilai Ham.

Lapas Maximum Security merupakan klasifikasi Lapas yang menekankan pada pola pembinaan untuk mendorong narapidana untuk taat dan tertib hukum, sadar akan perbuatan pelanggarnya dan menginternalisasi sikap dan perilaku dispilin. Narapidana yang di tempatkan pada tahap ini merupakan narapidana yang di pindahkan dari Lapas Super Maximum yang memenuhi syarat dengan turunnya tingkat resiko dan perubahan perilaku yang di dasarkan pada Litmas dan rekomendasi pada Sidang TPP. Pola pembinaan yang di terapkan dengan metode observasi terbatas. Dimana penempatan narapidana sudah di satukan dengan narapidana yang lain atau di kelompokkan. P

1. engelompokan narapidana di dasarkan atas risiko narapidana terhadap diulangnya tindak pidana, risiko keselamatan dan keamanan, jenis kelamin, dan potensi minat bakat. Sehingga dalam pembinaan yang diberikan pada narapidana bisa di laksankan secara individu maupun kelompok. Pembinaan yang di berikan kepada narapidana meliputi:Pembinaan kesadaran beragama;

2. Pembinaan kesadaraan berbangsa dan bernegara;

3. Pembinaan kesadaran hukum;

4. Konseling psikologi;

5. Rehabilitasi, dibagi menjadi 2 yakni Rehabilitasi Sosial dan Rehabilitasi medis. Rehabilitasi Sosial merupakan refungsionalisasi atau proses pengembangan ataupun pemulihan yang di lakukan secara terpadu agar narapidana mampu melakukan fungsi mental, fisik, maupun sosial secara wajar dalam lingkungan masyarakat sedangkan Rehabilitasi medis merupakan proses yang di lakukan untuk pengobatan terhadap narapidana yang mengalami ketergantungan terhadap obat-obat tertentu atau zat adiktif yang diatur di dalam Permenkumham No 12 Tahun 2017 Tentang Penyelenggaraan Layanan Rehabilitasi Narkotika Bagi Tahanan Dan Warga Binaan Pemasyarakatan. Rehabilitasi biasanya dilaksanakan bagi narapidan penyalahgunaan Narkotika, Psikotropika, dan Zat Adiktif lainnya;

6. Pembinaan kemampuan intelektual, merupakan pembinaan peningkatan kapasitas kecerdasan narapidana untuk membentuk karakter profesional. Bentuk kegiatan dalam pembinaan ini seperti kejar paket $B / C$ atau Pelatihan Pramuka. Pada tahap ini 
narapidana tidak di batasi hak reintegrasi akan tetapi tetap mempertimbangkan ketentuan dan Litmas serta rekomendasi pada sidang TPP. Upaya dalam pemulihan kondisi baik secara psikis maupun sosial serta pengembangan kapasitas narapidana juga menjadi fokus dan tidak hanya perubahan perilaku apabila di amati di dalam jenis pembinaan yang diberikan kepada narapidana. Tentunya hal ini sejalan dengan konsep utama Sistem Pemasyarakatan.

Pada Lapas Medium Security merupakan Lapas dengan perlakuan yang menitik beratkan pada persiapan pengembalian narapidana ke masyarakat dan narapidana sebagai subyek di perkuat dengan adanya pembinaan yang mengarahkan pada minat dan bakat yang menggali potensi narapidana untuk di kembangkan. Dimana dalam perlakuannya narapidana dapat mengembangkan diri yang selaras dengan hak mengembangkan diri. Oleh karena itu di dalam metode pembinaan narapidana guna megoptimalkan potensi terdapat klasifikasi pembinaan, yaitu Pendidikan dan pelatihan keterampilan tingkat pemula, Pendidikan dan pelatihan keterampilan tingkat lanjutan, dan Pendidikan dan pelatihan keterampilan tingkat mahir. Sehingga dalam pola yang di pakai Lapas Medium Security melakukan asimilasi dan pemagangan terhadap narapidana. Asimilasi merupakan proses pembauran narapidana dengan kehidupan lingkungan masyarakat yang nyata(Peraturan Pemerintah Republik Indonesia Nomor 31 Tahun 1999 Tentang Pembinaan Dan Pembimbingan Warga Binaan Pemasyarakatan., 1999).Sedangkan pemagangan merupakan kerjasama yang dilakukan oleh pihak Lapas dengan pihak dari luar untuk mempekerjakan narapidana di luar. Hal tersebut mengarahkan narapidana untuk memahami dan mampu mealksanakan nilai-nilai nyata yang ada di masyarakat. Sehingga dalam penempatan narapidana dalam huniannya guna optimalisasi program pembinaan dengan mempertimbangkan risiko pengulangan tindak pidana, risiko keselamatan dan keamanan, jenis kelamin dan potensi minat bakat.

Lapas Minimum Security merupakan Lapas dengan perlakuan yang menitik beratkan pemberian reintegrasi dan output pembinaan yang mengarahkan pada hasil produksi barang atau jasa berskala industri. Oleh karena itu narapidana diberikan kelonggaran dalam pengamanan dan diberikan kepercayaan serta tanggung jawab akibat perubahan sikap dan perilaku. Hal ini dilakukan untuk memotivasi narapidana meningkatkan kemandirian dan produktivitas narapidana. Perwujudan Lapas Minimum Security ialah Lapas terbuka. Dimana dalam konsep yang diterapkan Lapas terbuka dengan Community Based Corrections yakni metode pembinaan dengan melibatkan unsur masyarakat serta dengan memberikan pengamanan yang lebih minimum bahkan tanpa jeruji besi layaknya Lapas yang seperti pada umumya yang bertujuan reintegration (penyatuan kembali) dengan masyarakat.(Hamja, 2015) Sehinga dengan konsep yang ada Lapas terbuka memiliki tujuan: 
(1) Pemulihan kesatuan hidup, penghidupan, dan kehidupan narapidana di masyarakat; (2) Membantu narapidana dengan memberikan kesempatan menjalankan fungsi sosialnya di masyarakat; (3) menstimulus peningkatan peran Petugas Pemasyarakatan, masyarakat, dan narapidana dalam pembinaan; (4) Memberikan motivasi narapidana untuk meningkatkan kemampuan dan keterampilan sebagai bekal kembali masyarakat; (5) Menjalankan konsepsi di dalam 10 (sepuluh) prinsip Pemasyarakatan dalam kehidupan berbangsa dan bernegara.(Hamja, 2015) Oleh karena itu di dalam penempatnya narapidana di tempatkan di camp-camp yang telah di sediakan yang mempertimbangkan risiko pengulangan tindak pidana, risiko keselamatan dan keamanan, jenis kelamin, dan kompetensi kemampuan dan keahlian.

Apabila memperhatikan secara keseluruhan proses yang ada di dalam Revitalisasi penyelenggaraan tersebut telah memenuhi aspek-aspek Ham yang di amanatkan di dalam Undang-undang Nomor 39 Tahun 1999 tentang Hak Asasi Manusia dan Undang-undang No 12 Tahun 1995 tentang Pemasyarakatan. Sebagaimana konsep Pemasyarakatan tentang pemulihan kesatuan hidup, kehidupan, dan penghidupan narapidana guna mengembalikan narapidana ke masyarakat tetap menjadi tujuan Revitalisasi. Hal ini menunjukkan walapun adanya ide atau gagasan revitalisasi terhadap Pemasyarakatan, konsep pemidaan yang dilakukan kepada narapidana tetap sama yakni tidak memfokuskan pada balas dendam tetapi mengupayakan untuk menginsafkan narapidana untuk tidak mengulang perbuatan yang salah yang merugikan dirinya dan orang lain serta mendorong narapidana taat pada norma sosial masyarakat, agama, dan hukum yang berlaku. Serta tetap memandang narapidana tidak hanya sebagai obyek tetapi juga sebagai subyek yang sama dengan manusia lainnya yang harus di hormati hak asasinya. Walapun terdapat kebijakan-kebijakan yang membuat pembatasan hak narapidana dan klasifikasi penempatan narapidana hal tersebut merupakan strategi untuk melakukan perubahan sikap dan perilaku yang menyiapkan narapidana kembali ke masyarakat dan mengoptimalkan proses Pemasyarakatan. Sehingga dengan melihat konsep Revitalisasi tersebut dapat di simpulkan bahwa upaya perlakuan negara terhadap narapidana dengan Pemasyarakatan masih mengandung pemenuhan aspek Ham. Sehingga dengan strategi yang ada pada revitalisasi juga dapat memotivasi masyarakat untuk dapat memahami tujuan dan filosofi Pemasyarakatan dan berperan dalam upaya pemulihan narapidana kembali ke lingkungannya. Karena di dalam revitalisasi juga menekankan keterlibatan masyarakat pada proses perbaikan narapidana. 
Journal Publicuho

ISSN 2621-1351 (online), ISSN 2685-0729 (print)

Volume 3 Number 1 (February-April), (2020) pp.91 - 102

Accredited SINTA SK.NOMOR 28/E/KPT/2019

Open Access at: http://ojs.uho.ac.id/index.php/PUBLICUHO/index

DOI: 10.35817/jpu.v3i1.11514

\section{KESIMPULAN}

Babak baru optimalisasi Pemasyarakatan telah tercetus dengan adanya Revitalisasi Penyelenggaraan Pemasyarakatan yang menekankan perubahan sikap dan perilaku narapidana. Pemasyarakatan melalui Revitalisasi berupaya melakukan optimalisasi perlakuan terhadap narapidana perlu mendapatkan dukungan berbagai pihak terutama masyarakat. Tanpa adanya dukungan masyarakat proses yang pengembalian narapidana tidak akan optimal. Dampaknya narapidana akan tetap kembali mengulangi tindak pidananya karena ditinggalkan masyarakat. Penerimaan masyarakat terhadap narapidana sangatlah penting karena dengan adanya hal tersebut akan memotivasi narapidana untuk berperilaku baik akibat ikatan sosial antara masyarakat dengan narapidana sangat kuat. Semakin kuat ikatan sosail narapidana dengan masyarakat potensi pengulangan akan semakin kecil. Di sisi lain pemerintah perlu memberikan edukasi kepada masyarakat tentang peran Pemasyarakatan. Tanpa adanya edukasi masyarakat akan sulit paham dan mau terlibat proses pemulihan narapidana. Di sisi lain tanpa edukasi, narapidana akan mendapat stigma masyarakat dan sikap resistensi masyarakat tentunya akan sangat besar yang berdampak pada kebencian masyarakat pada akhirnya kejahatan akan semakin meningkat. Para akademisi harus berpartisipasi dalam kajian tentang Pemasyarakatan. Semakin banyak kajian hal ini kan membuat IImu Pemasyarakatan akan semakin maju dan permasalahan sosial masyarakat akan terurai. Karena pada dasarnya permasalahan yang ada di Lapas/ Rutan merupakan permasalahan yang ada di sekitar masyarakat.

\section{DAFTAR PUSTAKA}

Aryana, I. W. P. S. (2015). Efektivitas Pidana Penjara Dalam Membina Narapidana. Jurnal IImu Hukum Universitas Ngurah Rai, Vol. 11 (21).

Aswandi, B., \& Roisah, K. (2019). Negara Hukum Dan Demokrasi Pancasila Dalam Kaitannya Dengan Hak Asasi Manusia (Ham). Jurnal Pembangunan Hukum Indonesia, 1(1), 128. https://doi.org/10.14710/jphi.v1i1.128-145

Eddyono, S. W. (2017). "Overcrowding" yang Menghantui Lapas di Indonesia. Kompas. https://nasional.kompas.com/read/2017/07/07/12130041/.overcrowding.yang.menghan tui.lapas.di.indonesia? page=all

Fajriando, H. (2019). Evaluasi Pelaksanaan Community-Based Corrections Di Lapas Terbuka Kelas lii Rumbai ( The Evaluation of Community-Based Corrections in Rumbai Class 3 Open Correctional Facility ). Jurnal IImiah Kebijakan Hukum, 13, 323-338.

Hamja, H. (2015). Model Pembinaan Narapidana Berbasis Masyarakat (Community Based Corrections) Dalam Sistem Peradilan Pidana. Mimbar Hukum - Fakultas Hukum Universitas Gadjah Mada, 27(3), 445. https://doi.org/10.22146/jmh.15882 
Haryono. (2018). Optimalisasi Dalam Proses Asimilasi Narapidana (Optimization of the Implementation of Duties and Functions Open Prison in the Assimilation Process of Prisoners ). Vol. 12(3), 295-312.

Peraturan Pemerintah Republik Indonesia Nomor 31 Tahun 1999 Tentang Pembinaan Dan Pembimbingan Warga Binaan Pemasyarakatan., (1999).

Peraturan Menteri Hukum Dan Hak Asasi Manusia Republik Indonesia Nomor 35 Tahun 2018 Tentang Revitalisasi Penyelenggaraan Pemasyarakatan, Pub. L. No. 35 Tahun 2018 (2018).

Undang-Undang Nomor 12 tahun 1995 Tentang Pemasyarakatan, (1995).

Joseph, N. (2017). Sebenarnya Konsultasi ke Psikolog Itu Seperti Apa, Sih? Hellosehat.Com. https://hellosehat.com/hidup-sehat/psikologi/saat-konseling-psikologi/

Jufri, E. A. (2017). Pelaksanaan Asimilasi Narapidana Di Lembaga Pemasyarakatan Terbuka Jakarta. Jurnal Hukum Adil, Vol.8(1), 1-26.

Latifah, M. (2019). Overcrowded Pada Rumah Tahanan Dan Lembaga Pemasyarakatan Di Indonesia. Kajian Singkat Terhadap Isu Aktual Dan Strategis, 11.

Matompo, O. S. (2014). Pembatasan Terhadap Hak Asasi Manusia Dalam Prespektif Keadaan Darurat. Media Hukum, 21 (1), 57-72.

https://media.neliti.com/media/publications/ 1 13633-ID-pembatasan-terhadap-hak-asasimanusia-da.pdf

Michael, D. (2017). Penerapan Hak-Hak Narapidana Di Lembaga Pemasyarakatan Klas I A Tanjung Gusta, Sumatera Utara Ditinjau Dari Perspektif Hak Asasi Manusia. Jurnal Penelitian Hukum De Jure, 17.

Ryandi, D. (2019). Makin Banyak Orang Dipenjara, Biaya Makan Napi Tembus Rp 1,79 Triliun. Jawapos.Com. https://www.jawapos.com/nasional/27/12/2018/makin-banyak-orangdipenjara-biaya-makan-napi-tembus-rp-179-triliun/

Winarto, D. (2018). Anak LPKA Kutoarjo Mengikuti Pembinaan Kesadaran Berbangsa dan Bernegara. Ditjenpas.Go.ld. http://ditjenpas.go.id/pembinaan-kesadaran-berbangsabernegara-bentuk-karakter-anak-Ipka-kutoarjo 